\title{
HUBUNGAN PENDIDIKAN KEJURUAN DENGAN PRODUKTIVITAS KERJA PERSONIL POLRES KERINCI
}

\author{
M Dhany Al Sunah, S.Pd.,M.Pd \\ STIA NUSANTARA SAKTI SUNGAI PENUH \\ Email ; dhanyalsunah@gmail.com
}

\begin{abstract}
ABSTRACK
Relationship of Vocational Education with Work Productivity of Kerinci Police Personnel. With the Problem Formulation Is There a Relationship Between Vocational Education With Work Productivity Of Kerinci Police Personnel And Some Relationships Of Vocational Education With Work Productivity Of Kerinci Police Personnel. The Following Purpose of This Research To Determine the Relationship Between Vocational Education With Work Productivity Of Kerinci Police Personnel And Some Relationships Of Vocational Education With Work Productivity Of Kerinci Police Personnel.

This study uses a quantitative method in which research methods based on the philosophy of positivism are used to examine specific populations or samples. From the Research Results Using the Spearman Rank Correlation Known about Vocational Education Significantly Related to the Work Productivity of Kerinci Police Personnel.

The Conclusions Of This Research Are Related To The Significant Relationship Between Vocational Education To The Work Productivity Of Kerinci Police Personnel With Values.

Key word : Vocational Education, Work productivity
\end{abstract}




\section{PENDAHULUAN}

Seiring dengan kemajuan zaman dampak perubahn fenomena pandangan yang berbeda dari masa sebelumnya, fenomena tersebut adalah semakin besarnya perhatian berbagai pihak terhadap pentingnya manajemen sumber daya manusia. Sebagaimana diketahui pada masa sekarang ini, besar sekali perkembangan sumber daya manusia diberbagai media. Sumber daya manusia dipandang sebagai salah satu faktor terpenting, bagi suatu negara, sumber daya manusai merupakan aset terpenting dalam penyelengaraan pemerintahannya. Suatu negara yang tidak memiliki sumber daya manusia dan kekayaan alam, akan tetapi jika mempunyai sumber daya manusia yang terdidik, terampil, berdisiplin, tekun, mau bekerja keras dan setia kepada cita-cita perjuangan, bangsanya, ternyata berhasil meraih kemajuan yang sangat begitu besar yang bahkan semua Negara lain kagum terhadapapnya.

Logikanya bahwa negara-negara yang sekaligus memiliki sumber daya, kekayaan alam dan sumber daya manusia lebih mudah mencapai kemajuan yang didambakan oleh masyarakat, akan tetapi sebaliknya sumber daya non manusia dan kekayaan alam yang melimpah ternyata tidak banyak artinya tanpa dikelola manusia secara baik artinya, sumber daya lain dan kekayaan alam tetap merupakan modal yang amat berharga, akan tetapi modal tersebut hanya ada artinya apabila digunakan oleh manusia, tidak hanya bagi kepentingan diri sendiri, akan tetapi demi kesejahteraan masyarakat sebagai keseluruhan.

Perlu adanya manajemen sumber daya manusia handal, pengelolaan, penggunaan dan pemanfaatan sumber-sumber lainnya yang jadi tidak berdaya guna dan berhasil guna. Dalam situasi tersebut tidak mustahil gambaran tentang usaha pencapaian tujuan nasional menjadi kabur yang dapat berakibat pada kegelisahan atau keresahan dikalangan masyarakat, pentingnya pemanfaatan sumber daya manusia yang professional melalui pendidikan kejuruan sangatlah penting untuk membangun sumber daya manusia yang berkualitas.

Kemampuan dalam penelitian ini berarti seorang aparat pada Polres Kerinci yang memiliki kecakapan atau kesanggupan untuk mengerjakan sesuatu yang diwujudkan melalui tindakanya untuk meningkatkan produktifitas kerja. Peraturan Kepala Kepolisian Negara Republik Indonesia Nomor 14 tahun 2015 Tentang Sistem Pendidikan Kepolisian Negara Republik Indonesia Pasal 1 ayat 6 menyatakan bahwa Pendidikan Polri adalah usaha sadar dan terencana untuk mewujudkan suasana proses pembelajaran, pelatihan, dan pengasuhan guna membentuk dan mengembangkan pengetahuan, sikap perilaku, dan keterampilan peserta didik pada Satuan Pendidikan Polri.

Sejalan dengan uraian di atas bahwa pendidikan kejuruan bagi kepolisian sangatlah penting guna untuk memiliki kecakapan dan kesanggupan untuk mengerjakan sesuatu yang diwujudkan melalui tindakannya untuk meningkatkan produktifitas kerja dalam melaksanakan tugas. 
Faktor kualitas kepolisian merupakan salah satu hal yang pertama kali ingin ditingkatkan. Hal ini ditujukan sebagai pencerminan keinginan seluruh polisi yang ada di Polres Kerinci untuk memeberikan pelayanan terbaik kepada masyarakat.

Tinggi rendahnya kemampuan kerja kepolisian Polres Kerinci dalam pelayanan masyarakat dapat diukur dari sejauh mana hubungan pendidikan kejuruan yang pernah mereka ikuti dapat mempengaruhi keterampilan dan kemapuan serta penguasaan pekerjaan kepolisian sehinga dapat memberikan kepuasan kerja yang maksimal serta menghasilkan output kerja yang optimal. Hal ini cukup beralasan karena berdasarkan kemapuan kerja ini merupakan faktor yang mencerminkan sikap dan karakter kepolisian dalam melaksanakan tugas dan fungsinya.

Memiliki sumber daya manusia yang profesional, loyal, berdedikasi tinggi dan terjamin, dengan menyadari bahwa sumber daya manusia adalah aset yang sangat berarti, yang mengerakkan seluruh roda organisasi, maka pengembangan sumber daya manusia di tempatkan pada urutan tertinggi, dengan demikian tujuan organisasi dan dengan sendirinya secara timbal balik memberikan kesejahteraan kepada kepolisian Polres Kerinci.

Kegiatan-kegiatan yang dilaksanakan Polres Kerinci ternyata masih mengutamakan pergerakan berdasarkan aturan-aturan yang kaku dengan mengabaikan seni dan gaya para kepolisian dalam bekerja seakan-akan dipaksakan tanpa adanya semangat untuk bekerja suatu pekerjaan yang membutuhkan perencanaan yang teliti untuk mendapatkan hasil kerja yang baik dan memuaskan, dengan bertambahnya volume pekerjaan dengan rasa penuh tanggung jawab, selain itu upaya peningkatan kinerja tidak dapat dilakukan dengan baik karena kinerja dapat dipengaruhi oleh tingkat pendidikan masing-masing polisi terutama pada pendidikan kejuruan demi meningktakan produktifitas kinerja personil polisi.

\section{Tinjauan Pustaka}

\subsection{Pengertian Hubungan}

Hubungan adalah sesuatu yang terjadi apabila dua orang atau hal atau keadaan saling mempengaruhi dan saling bergantung antara satu dengan yang lainnya. Menurut Tams Jayakusuma (2001:25), hubungan adalah suatu kegiatan tertentu yang membawa akibat kepada kegiatan yang lain. Selain itu arti kata hubungan dapat juga dikatakan sebagai suatu proses, cara atau arahan yang menentukan atau menggambarkan suatu obyek tertentu yang membawa dampak atau pengaruh terhadap obyek lainnya.

Hubungan adalah kesinambungan interaksi antara dua orang atau lebih yang memudahkan proses pengenalan satu akan yang lain. Hubungan terjadi dalam setiap proses kehidupan manusia. Hubungan dapat dibedakan menjadi hubungan dengan teman sebaya, orangtua, keluarga, dan lingkungan sosial. Secara garis besar, hubungan terbagi menjadi hubungan positif dan negatif. Hubungan positif terjadi apabila kedua pihak yang berinteraksi merasa saling diuntungkan satu sama lain 
dan ditandai dengan adanya timbal balik yang serasi. Sedangkan, hubungan yang negatif terjadi apabila suatu pihak merasa sangat diuntungkan dan pihak yang lain merasa dirugikan. Dalam hal ini, tidak ada keselarasan timbal balik antara pihak yang berinteraksi.Lebih lanjut, hubungan dapat menentukan tingkat kedekatan dan kenyamanan antara pihak yang berinteraksi. Semakin dekat pihak-pihak tersebut, hubungan tersebut akan dibawa kepada tingkatan yang lebih tinggi.

\subsection{Pengertian Pendidikan Kejuruan.}

Pendidikan kejuruan adalah pendidikan menengah yang mempersiapkan peserta didik terutama untuk bekerja dalam bidang tertentu.

Defenisi pendidikan kejuruan menurut para ahli :

a) Menurut Soeharto (1988:1)

mengemukakan vocational education (pendidikan kejuruan) adalah pendidikan khusus yang program-programnya atau materi pelajarannya dipilih untuk siapapun yang tertarik untuk mempersiapkan diri bekerja sendiri, atau untuk bekerja sebagai bagian dari suatu grup kerja

b) Menurut Muliati (2007:7) mengemukakan pendidikan kejuruan adalah bagian dari sistem pendidikan yang mempersiapkan seseorang agar lebih mampu bekerja pada satu kelompok pekerjaan atau satu bidang pekerjaan daripada bidang-bidang pekerjaan lain.

c) Menurut Djohar (2007:128) mengemukakan pendidikan kejuruan adalah suatu program pendidikan yang menyiapkan individu peserta didik menjadi tenaga kerja yang professional

d) Menurut Roy W. Robert (dalam Soeharto, 1988:2) adalah pendidikan kejuruan yang bidang keahliannya meliputi masalah teknik industri. Dijelaskan pula bahwa pendidikan teknik yang dilaksanakan di berbagai fakultas teknik di lingkungan perguruan tinggi tidak termasuk di dalamnya.

Dari pendapat ahli di atas dapat disimpulkan bahwa pendidikan kejuruan merupakan suatu sistem pendidikan yang mempersiapkan individu-individu profesional agar lebih mampu bekerja pada satu kelompok pekerjaan atau satu bidang pekerjaan dan menjadi manusia yang produktif dan memiliki skill.

\subsection{Tujuan Pendidikan Kejuruan}

Secara umum pendidikan kejuruan bertujuan untuk memberikan kesempatan kepada personalia dalam meningkatkan kecakapan dan keterampilan mereka, terutama dalam bidang-bidang yang berhungan dengan kepemimpinan atau manajerial yang diperlukan dalam pencapaian tujuan.

Menurut Hadiyanto (1992: 45) Mengemukakan beberapa tujuan pendidikan kejuruan yaitu : 
a. Bekerja lebih efisien, siapapun yang mengikuti pendidikan kejuruan diharapakan kelak bias bekerja lebih efisien. Setelah mengikuti pendidikan kejuruan tentunya para personil bertambah pengetahuannya, sehingga lebih mudah dalam menyelesaikan tugas.

b. Pengawasan lebih sedikit, setelah mengikuti pendidikan kejuruan, maka kesalahan dalam melaksanakan tugas tentunya dapat diminimalisir. Jika kesalahan yang mungkin dibuat hanya sedikit maka tingkat pengawasan yang diberikan menjadi lebih sedikit.

c. Lebih cepat berkembang, perkembangan personil memang dapat dibiarkan secara alami sesuai dengan kemampuannya. Akan tetapi perkembangan tersebut akan lebih cepat jika para personil mengikuti pendidikan kejuruan.

d. Stabilitas pegawai dan penurunan turn over, para personil yang telah memperoleh pendidikan kejuruan secara berhasil dan dapat berkembang maka mempunyai kecenderungan untuk bertahan.

Menurut Fatoni (2006 : 98) Bahwa tujuan pendidikan kejuruan pada umumnya dalam rangka pembinaan terhadap para personil agar mendapatkan :

a. Meningkatkan kepribadian dan semangat pengabdian.

b. Meningkatkan mutu dan kemampuan, serta keterampilan baik dalam melaksanakan tugasnya maupun kepemimpinanya.

c. Melatih dan meningkatkan mekanisme kerja dan kepekaan dalam melaksanakan tugas

d. Melatih dan meningkatkan kerja dalam perencaan.

Peraturan Pemerintahan (PP) Nomor 101 tahun 2000 tentang pendidikan kejuruan menjelaskan bahwa tujuan pendidikan kejuruan adalah :

a. Meningkatkan pengetahuan, keahlian, keterampilan dan sikap untuk dapat melaksanakan tugas jabatan secara professional dengan di landasi kepribadian dan etika sesuai dengan kebutuhan.

b. Menciptakan personil yang mampu berperan sebagai pembaharuan dan perekat persatuan dan kesatuan bangsa.

c. Menetapkan sikap dan semangat pengabdian yang berorientasi pada pelayanan, pengayoman dan pemberdayaan masyarakat.

d. Menciptakan kesamaan visi dan dinamika pola pikir dalam melaksanakan tugas.

Berdasarkan beberapa tujuan pendidikan kejuruan yang telah di paparkan diatas terdapat pendidikan kejuruan dengan meningkatkan produktivitas kinerja personel Polres Kerinci.

Tujuan pendidikan Kejuruan yang berkaitan dengan indikator dari kinerja yaitu :

1. Melatih dan meningkatkan mekanisme kerja dan kepekaan melaksanakan tugas berkaitan dengan indikator kinerja yaitu kualitas dan inisiatif dalam bekerja. 
2. Meningkatkan ilmu pengetahuan dan keterampilan kerja berkaitan dengan indikator kinerja yaitu pengetahuan.

3. Meningkatkan kepribadian dan semangat pengabdian kepada organisasi dan masyarakat berkaitan dengan indikator kinerja yaitu tanggung jawab. Meningkatkan pengetahuan ,keahlian, keterampilan dan sikap untuk dapat melaksanakan tugas secara professional dengan dilandasi kepribadian dan etika personil Polres Kerinci sesuai dengan kebutuhan berkaitan dengan indikator kinerja yaitu disiplin kerja.

Tujuan Pendidikan kejuruan diatas menunjukan bahwa pendidikan kejuruan memiliki hubungan terhadap Kerja personil Polres Kerinci, hal tersebut bias dilihat dari tujuan dari kejuruan yang sejalan dengan indikator pengukuran kinerja. Pendidikan kejuruan juga memiiki beberapa manfaat yang sangat penting.

\subsection{Manfaat Pendidikan Kejuruan}

Menurut Wursanto (1989 : 60-61), ada berbagai manfaat pendidikan kejuruan, yaitu

1. Pendidikan kejuruan meningkatkan stabilitas personil, artinya hubungan pergantian dengan personil lainnya yang tidak hadir.

2. Pendidikan kejuruan dapat memperbaiki cara kerja personil, artinya personil lebih kreatif dalam menjalankan pekerjaannya.

3. Pendidikan kejuruan memberi manfaat yang sangat baik bagi personil, karena dengan pendidikan kejuruan personil dapat berkembang dengan cepat, efisien dan melaksanakan tugas dengan baik.

4. Pendidikan kejuruan memberi kesempatan untuk mengembangkan diri.

Tujuan dan manfaat pendidikan kejuruan yang telah di paparkan, maka dapat di simpulkan bahwa tujuan pendidikan kejuruan yaitu untuk meningkatkan pengetahuan, kemampuan, dan keterampilan personil Polres Kerinci agar lebih profesional dalam menjalankan pekerjaannya sehinga tujuan dapat tercapai dan memiliki keterkaitan dengan kinerja personil. Sedangkan manfaat pendidikan kejuruan yaitu untuk meningkatkan stabilitas personil dan dapat memberikan kesempatan bagi personil untuk mengembangkan diri agar dalam melaksanakan tugas dapat berjalan dengan efektif dan efisien.

\subsection{Tahap-tahap pendidikan kejuruan.}

Menurut Sondang p siagian (2003: 185-187) Bahwa ada tahap-tahap yang perlu di temput dalam pendidikan kejuruan. Langkah-langkah tersebut, yaitu :

a. Penentuan kebutuhan

Analisis kebutuhan itu harus mampu mendiagnosa paling sedikit dua hal yaitu masalah-masalah yang di hadapi sekarang dan berbagai tantangan baru yang di perkirakan akan timbul di masa depan.

b. Penentuan sasaran 
Sasaran yang ingin di capai itu dapat bersifat teknikal akan tetapi dapat pula menyangkut tingkah laku atau mungkin juga keduanya. berbagai sasaran harus di nyatakan sejelas dan nyata mungkin, baik bagi para pelatih maupun para peserta.

c. Penetapan isi program

Sifat suatu program pendidikan kejuruan di tentukan paling sedikit oleh dua faktor, yaitu hasil analisis penentuan kebutuhan dan sasaran yang hendak di capai.

d. Identifikasi prinsi-prinsip belajar

Prinsip belajar yang layak di pertimbangkan untuk diterpakan berkisar pada lima hal, yaitu partisipasi (keterlibatan), repetisi (pengulangan), relevansi (kecocokan), pengalihan dan umpan balik.

e. Pelaksanaan program

Penyelenggaraan program pelatihan sangat situasional sifatnya, artinya dengan penekanan pada perhitungan kepentingan organisasi dan kebutuhan para peserta, penerapan prinsip-prinsip belajar tercermin pada pengunaa teknik-teknik tertentu dalam proses belajar mengajar.

f. Penilaian pelaksanaan program

Pelaksanaan program pendidikan kejuruan dapat dikatakan berhasil apabila dalam diri para perserta pendidikan kejuruan tersebut terjadi suatu proses transformasi. Proses transformasi dapat dikatakan baik apabila terjadi dua hal, yaitu peningkatan kemampuan dalam melaksanakan tugas dan perubahan sikap perilaku yang tercermin dalam sikap, disiplin, dan etos kerja.

\subsection{Komponen-komponen Pendidikan kejuruan.}

Dalam melaksanakan pendidikan kejuruan ada beberapa komponen yang berperan didalamnya menurut bintoro (2014:90), yaitu :

1. Standar kompentensi

Merupakan suatu kemapuan baku (patokan kemampuan) yang dilandasi oleh pengetahuan keterampilan dan didukung sikap kerja yang diperlukan dalam melaksanakan suatu tugas pekerjaan ditempat kerja. Standar kompentensi pada hakekatnya mengacu pada unjuk kerja yang di formulasikan atau di persyaratkan.

2. Tujuan

Merupakan sesuatu yang ingin di capai dalam suatu kegiatan, organisasi, lembaga/instansi. Tujuan dirumuskan dalam rangka membantu perencanaan suatu kegiatan lembaga/instansi.

Penentuan tujuan diharapkan dapat mendukung suatu kegiatan yang di laksanakan menjadi lebih terarah dan sistimetis. Program pendidikan 
kejuruan juga tidak terlepas dari perumusan suatu tujuan. Berdasarkan uraian sebelumnya bahwa kegiatan pendidikan kejuruan memiliki tujuan untuk meningkatkan kemampuan, pengetahuan, skill seseorang dalam menunjang pekerjaannya,

3. Metode

Metode dalam dunia pendidikan kejuruan sangat bervariatif, metodemetode yang ada tidak dapat ditetapkan mana yang paling baik dan kurang baik, karena pada dasarnya penerapan metode dalam suatu pendidikan kejuruan disesuaikan dengan kebutuhan dalam pendidikan kejuruan itu sendiri.

\subsection{Metode pendidikan kejuruan}

Metode pendidikan kejuruan merupakan pendekatan terhadap cara penyelengaraan dan pelasanaan pendidikan kejuruan .

Menurut Notoatmodjho (2003 : 37-40) terdapat ada dua macam metode yang digunakan dalam pendidikan kejuruan personil, yaitu :

a. Metode on the job site (pelatihan didalam pekerjaan)

Pelatihan ini berbentuk penugasan personil-personil baru pada personil yang telah berpengalaman (senior). Hal ini berarti personil baru, meminta kepada para personil yang sudah berpengalaman untuk membimbing atau mengajarkan pekerjaan yang baik kepada para personil baru.

Menurut Handoko (2001: 112) "Metode" on the job site" merupakan metode latihan yang paling banyak digunakan ". Latihan dengan mengunakan metode ini dilakukan ditempat kerja.personil dilatih tentang pekerjaan baru dengan super visi langsung seorang pelatih yang berpengalaman (biasanya personil lain).

Keuntungan metode on the job site adalah :

1. Biaya dapat ditekan serendah mungkin. Karena tidak perlu mengeluarkan biaya sewa tempat dan peralatan yang di gunakan.

2. Tidak diperlukan masa penyesuaian atau pengenalan terhadap, teman maupun lingkungan

3. Telah terjalin komunikasi yang baik antar peserta dan pengajar sehinga dapat dijamin adanya kelancaran program pelatihan.

Kelemahan metode on the job site adalah :

1. Tidak mudah memperoleh pengajar dari dalam karena adanya keterbatasan kempauan atau waktu.

2. Jumlah peserta harus memenuhi rasio yang menguntungkan.

3. Sulitnya mengatur waktu belajar, artinya banya hal-hal yang harus di pertimbangkan.

b. metode off the job site (latihan diluar pekerjaan)

Pendidikan kejuruan dengan mengunakan metode ini karena memberikan kesempatan kepada individu untuk lebih berkonsentrasi terhadap apa yang harus di 
pelajari. Selain itu, pertemuan dengan peserta yang lain membuat mereka mendapatkan wawasan baru.

\subsection{Prinsip-prinsip pendidikan kejuruan}

Yang di maksud dengan pendidikan kejuruan adalah keseluruhan kegiatan untuk memberi, memperoleh dan meningkatkan kemampuan kerja. Salah satu jenis pendidikan di dunia ini adalah pendidikan kejuruan. Menurut Arikunto (1988) pendidikan kejuruan berkembang semenjak adanya Akte Pendidikan Kejuruan (Vocational Education Act of 1963).

Lebih lanjut disebutkan bahwa perkembangan ini ditandai oleh pesatnya perkembangan fasilitas fisik untuk melayani kebutuhan banyak orang dalam lingkup pendidikan kejuruan yang semakin luas, tetapi tersedianya pelayanan belum sepadan dengan tuntutan. Prinsip pendidikan kejuruan antara lain :

1. Pendidikan kejuruan akan efektif jika dapat memampukan setiap individu memodali minatnya, pengetahuannya dan keterampilannya pada tingkat yang paling tinggi.

2. Pendidikan kejuruan yang efektif untuk setiap profesi, jabatan atau pekerjaan hanya dapat diberikan kepada seseorang yang memerlukannya, yang menginginkannya dan yang mendapat untung darinya

3. Pendidikan kejuruan akan efektif jika pengalaman latihan untuk membentuk kebiasaan kerja dan kebiasaan berpikir yang benar diulang-ulang sehingga sesuai seperti yang diperlukan dalam pekerjaan nantinya.

4. Pada setiap jabatan ada kemampuan minimum yang harus dipunyai oleh seseorang agar dia tetap dapat bekerja pada jabatan tersebut.

5. Pendidikan kejuruan akan efektif jika pengalaman latihan untuk membentuk kebiasaan kerja dan kebiasaan berpikir yang benar diulang-ulang sehingga sesuai seperti yang diperlukan dalam pekerjaan nantinya, jenis Pendidikan Kejuruan :

1. Brimob

2. Samapta

3. Lalu Lintas

4. Reskrim

5. Intel

6. Administrasi

7. Pol Air

8. Sekolah Penerbangan

\subsection{Indikator Pendidikan Kejuruan}

Soekidjo Notoatmodjo, (2003:16) mendefinisikan secara umum "Pendidikan kejuruan adalah segala upaya yang direncanakan untuk mempengaruhi orang lain baik individu, kelompok, atau masyarakat sehingga mereka melakukan apa yang diharapkan oleh pelaku pendidikan." Untuk mengukurnya dapat di lihat pada indikator di bawah : 
1. Pengembangan Kompentensi

Pengembangan Kompentensi adalah kemapuan teknis pegawai dalalam bidang-bidang teknis untul pelaksanaan tugas melalui program pendidikan dan pelatihan, juga dapat melalui kursus, penataran, dan seminar.

2. Disiplin

Disiplin adalah kepatuhan seseorang dalam mengikuti peraturan atau tata tertib karena didorong oleh adanya kesadaran yang ada pada kata hatinya tanpa adanya paksaan dari pihak luar

3. Sikap

Sikap adalah keyakinan atau pendapat seseorang terkait situasi, subjek atau objek yang disertai dengan munculnya perasaan tertentu.

4. Etos kerja

Etos kerja adalah sikap yang muncul atas kehendak dan kesadaran sendiri yang didasari oleh system orientasi nilai budaya terhadap kerja

\subsection{Pengertian produktivitas}

Produktifitas mengandung pengertian filosofis, definisi kerja dan teknis operasional, secara filosofis, produktifitas mengandung pandangan hidup dan sikap mental yang selalu berusaha untuk meningkatkan mutu kehidupan. Keadaan hari ini harus lebih baik dari kemarin, dan mutu kehidupan besok harus lebih baik dari hari ini. Pandangan hidup dan sikap mental yang demikian akan mendorong manusia untuk tidak cepat merasa puas dan akan terus meningkatkan kemampuan kerjanya.

Untuk definisi kerja, produktifitas merupakan perbandingan antara hasil yang dicapai (keluaran) dengan keseluruhan sumber daya (masukan) yang dipergunakan per satuan waktu, definisi kerja ini mengandung cara atau metode pengukuran, walaupun secara teori dapat dilakukan tetapi secara praktek sukar dilaksanakan, dikarenakan sumber daya masukan yang dipergunakan umumnya terdiri dari banyak macam dengan proporsi yang berbeda. (Hasibuan Malayu S.P 2003).

\subsection{Indikator Produktivitas Kerja}

Produktivitas kinerja adalah catatan tentang hasil yang diperoleh dari fungsi-fungsi pekerjaan tertentu atau kegiatan selama kurun waktu tertentu. Menurut Bernardin \& Russel (2003) untuk mengukur kinerja karyawan dapat digunakan beberapa kriteria kinerja, antara lain adalah:

1. Kualitas

Kualitas adalah tingkat baik buruknya atau taraf derajat sesuatu dalam pekerjaan.

2. Kuantitas

Kuantitas adalah segala macam bentuk satuan ukuran yang berhubungan dengan jumlah hasil kerja yang bias dinyatakan dalam ukuran angka atau padanan angka lainya. 
3. Ketepantan waktu

Ketepatan waktu merupakan di mana kegiatan tersebut dapat diselesaikan, atau suatu hasil produksi dapat dicapai, pada permulaan waktu yang ditetapkan bersamaan koordinasi dengan hasil produk yang lain dan memaksimalkan waktu yang tersedia untuk kegiatan-kegiatan lain.

4. Inisiatif

Inisiatif adalah kemapuan seseorang untuk menghasilkan sesuatu yang baru atau asli atau menghasilkan suatu pemecahan masalah

5. Kerja sama

Kerja sama adalah sebuah usaha yang dilakukan oleh beberapa orang atau kelompok untuk mencapai tujuan bersama.

\subsection{Kerangka Pemikiran}

Untuk mempermudah pemahaman dalam penelitian ini dapat di gambarkan dengan kerangka pemikiran dalam bagan skematis sebagai berikut :

Gambar 2.12

Kerangka Pemikiran

\begin{tabular}{|l|l|}
\hline Variable X Pendidikan Kejuruan & \multicolumn{1}{c|}{$\begin{array}{c}\text { Variable Y Produktivitas } \\
\text { Kinerja }\end{array}$} \\
1. Pengembangan kompetensi & \multicolumn{1}{|c}{. Disiplin } \\
3. Sikap & $\begin{array}{l}\text { 1. Kualitas } \\
\text { 2. Kuantitas } \\
\text { 4. Etos kerja }\end{array}$ \\
3. Ketetapan waktu \\
2003:16)
\end{tabular}

2.13 Hipotesis

untuk menguji hipotesis yang telah dikemukakan maka dilakukan uji t dengan rumus yang mengacu sugiyono (2006:216) sebagai berikut :

$$
\mathbf{T} \text { hitung }=\frac{\mathbf{r} \sqrt{\mathbf{n}-2}}{\sqrt{1-r^{2}}}
$$

Keterangan :

$\mathrm{t}$ hitung $=$ nilai $\mathrm{t}$

$\mathrm{r} \quad=$ nilai koefisien korelasi

$\mathrm{n} \quad=$ jumlah sample dimana sample sama dengan populasi 
alat yang digunakan dalam pembuktian hipotesis adalah uji t hitung dengan kriteria sebagai berikut :

1. t hitung $>$ table maka hipotesis nol ditolak dan hipotesa alternative diterima artinya ada hubungan pendidikan kejuruan terhadap meningkatkan produktivitas kinerja pada personil Polres Kerinci.

2. t hitung < table maka hipotesa no diterima dan hipotesa alternative ditolak artinya tidak ada hubungan meningkatkan produktivitas kinerja pada personil Polres Kerinci.

t table $=(0,5-a / 2)$

Keterangan :

$\mathrm{t} t \mathrm{tab}=\mathrm{t}$ table

$\mathrm{t}$ tab $=$ kesalahan nyata dalam hal ini ditentukan $5 \%$

dari hasil analisis tersebut, apabila hasil thitung lebih besar dari table berarti adanya hubungan pendidikan kejuruan (variable $\mathrm{X}$ ) dengan Produktivitas Kerja Personil (variable Y).

\section{Metode Penelitian}

Pendekatan ini menggunakan penelitian Kuantitatif. Menurut Sugiyono, metode penelitian kuantitatif dapat diartikan sebagai metode penelitian yang berlandaskan pada filsafat positivisme, digunakan untuk meneliti pada populasi atau sampel tertentu. Teknik pengambilan sampel pada umumnya dilakukan secara random, pengumpulan data menggunakan instrumen penelitian, analisis data bersifat kuantitatif/statistik dengan tujuan untuk menguji hipotesis yang telah ditetapkan (Sugiyono, 2012: 7).

\section{HASIL DAN PEMBAHASAN}

\section{Pernyataan mengenai pengembangan kompentensi}

Berdasarkan angket yang disebarkan, peneliti memberikan penilaian mengenai pengembangan kompentensi yang dapat dilihat pada tabel 4.1 di bawah ini :

Tabel 4.1

Jawaban Responden Mengenai

Pengembangan Kompentensi

$\mathrm{N}=20$

\begin{tabular}{|c|l|c|c|c|}
\hline No & \multicolumn{1}{|c|}{ Alternatif Jawaban } & \multirow{2}{*}{ Angket } & Frekuensi & $\begin{array}{c}\text { Persentase } \\
(\boldsymbol{\%})\end{array}$ \\
\hline 1. & Sangat Setuju (SS) & & 13 & $32.50 \%$ \\
\hline 2. & Setuju (S) & \multirow{2}{*}{20} & 25 & $67.50 \%$ \\
\cline { 5 - 5 } \cline { 4 - 5 } 3. & Ragu-Ragu (RR) & & 0 & $00.00 \%$ \\
\hline
\end{tabular}




\begin{tabular}{|c|l|c|c|c|}
\hline 4. & Tidak Setuju (TS) & & 0 & $00.00 \%$ \\
\hline 5. & Sangat Tidak Setuju (STS) & & 0 & $00.00 \%$ \\
\cline { 4 - 5 } & Jumlah & $\mathbf{2 0}$ & $\mathbf{3 8}$ & $\mathbf{1 0 0 . 0 0 \%}$ \\
\hline
\end{tabular}

Sumber Data : Hasil Penelitian 2019

Berdasarkan hasil penyebaran angket yang disebarkan sebanyak 20 angket yang masing-masing indikator terdiri dari 2 pertanyaan sebagaimana terlihat pada tabel 3.4 di atas, mayoritas responden menjawab setuju sebanyak 67,50\%, hal ini berarti bahwa hubungan pendidikan kejuruan di bidang pengembangan kompentensi telah sesuai dengan yang diharapkan.

\section{Disiplin}

Berdasarkan angket yang disebarkan, peneliti memberikan penilaian mengenai disiplin yang dapat dilihat pada tabel 4.2 di bawah ini :

\section{Tabel 4.2}

Jawaban Responden Mengenai

Disiplin

$\mathrm{N}=20$

\begin{tabular}{|c|l|c|c|c|}
\hline No & \multicolumn{1}{|c|}{ Alternatif Jawaban } & \multirow{2}{*}{ Angket } & Frekuensi & $\begin{array}{c}\text { Persentase } \\
(\mathbf{\%})\end{array}$ \\
\hline 1. & Sangat Setuju (SS) & & 2 & $5.00 \%$ \\
\hline 2. & Setuju (S) & & 33 & $87.50 \%$ \\
\cline { 5 - 5 } 3. & Ragu-Ragu (RR) & \multirow{2}{*}{20} & 3 & $7.50 \%$ \\
\hline 4. & Tidak Setuju (TS) & & 0 & $0.00 \%$ \\
\cline { 5 - 5 } 5. & Sangat Tidak Setuju (STS) & & 0 & $0.00 \%$ \\
\hline & Jumlah & $\mathbf{2 0}$ & $\mathbf{3 8}$ & $\mathbf{1 0 0 . 0 0 \%}$ \\
\hline
\end{tabular}

Sumber Data : Hasil Penelitian 2019

Berdasarkan hasil penyebaran angket yang disebarkan sebanyak 20 angket yang masing-masing indikator terdiri dari 2 pertanyaan sebagaimana terlihat pada tabel 3.5 di atas, mayoritas responden menjawab setuju sebanyak $87,50 \%$, hal ini berarti bahwa hubungan pendidikan kejuruan di bidang disiplin telah sesuai dengan yang diharapkan.

\section{Sikap}

Berdasarkan angket yang disebarkan, peneliti memberikan penilaian mengenai sikap yang dapat dilihat pada tabel 4.3 di bawah ini :

Tabel 4.3

Jawaban Responden Mengenai

$$
\begin{aligned}
& \text { Sikap } \\
& \mathrm{N}=20
\end{aligned}
$$




\begin{tabular}{|c|c|c|c|c|}
\hline No & Alternatif Jawaban & Angket & Frekuensi & $\begin{array}{c}\text { Persentase } \\
(\%)\end{array}$ \\
\hline 1. & Sangat Setuju (SS) & \multirow{5}{*}{20} & 18 & $45.00 \%$ \\
\hline 2. & Setuju (S) & & 20 & $55.00 \%$ \\
\hline 3. & Ragu-Ragu (RR) & & 0 & $00.00 \%$ \\
\hline 4. & Tidak Setuju (TS) & & 0 & $00.00 \%$ \\
\hline 5. & Sangat Tidak Setuju (STS) & & 0 & $00.00 \%$ \\
\hline & Jumlah & 20 & 38 & $100.00 \%$ \\
\hline
\end{tabular}

Sumber Data : Hasil Penelitian 2019

Berdasarkan hasil penyebaran angket yang disebarkan sebanyak 20 angket yang masing-masing indikator terdiri dari 2 pertanyaan sebagaimana terlihat pada tabel 3.6 di atas, mayoritas responden menjawab setuju sebanyak 55,00\%, hal ini berarti bahwa hubungan pendidikan kejuruan di bidang sikap telah sesuai dengan yang diharapkan.

\section{Etos Kerja}

Berdasarkan angket yang disebarkan, peneliti memberikan penilaian mengenai Etos Kerja yang dapat dilihat pada tabel 4.4 di bawah ini :

Tabel 4.4

Jawaban Responden Mengenai

Etos Kerja

$\mathrm{N}=20$

\begin{tabular}{|c|c|c|c|c|}
\hline No & Alternatif Jawaban & Angket & Frekuensi & $\begin{array}{c}\text { Persentase } \\
(\%)\end{array}$ \\
\hline 1. & Sangat Setuju (SS) & \multirow{5}{*}{20} & 9 & $22.50 \%$ \\
\hline 2. & Setuju (S) & & 17 & $47.50 \%$ \\
\hline 3. & Ragu-Ragu (RR) & & 12 & $30.00 \%$ \\
\hline 4. & Tidak Setuju (TS) & & 0 & $00.00 \%$ \\
\hline 5. & Sangat Tidak Setuju (STS) & & 0 & $00.00 \%$ \\
\hline & Jumlah & 20 & 38 & $100.00 \%$ \\
\hline
\end{tabular}

Sumber Data : Hasil Penelitian 2019

Berdasarkan hasil penyebaran angket yang disebarkan sebanyak 20 angket yang masing-masing indikator terdiri dari 2 pertanyaan sebagaimana terlihat pada tabel 4.4 di atas, mayoritas responden menjawab setuju sebanyak 47,50\%, hal ini berarti bahwa hubungan pendidikan kejuruan di bidang etos kerja telah sesuai dengan yang diharapkan.

\section{Produktivitas}


Berdasarkan angket yang disebarkan, peneliti memberikan penilaian mengenai Produktivitas yang dapat dilihat pada tabel 4.5 di bawah ini :

Tabel 4.5

Jawaban Responden Mengenai Produktivitas

$\mathrm{N}=20$

\begin{tabular}{|c|l|c|c|c|}
\hline No & \multicolumn{1}{|c|}{ Alternatif Jawaban } & \multirow{2}{*}{ Angket } & Frekuensi & $\begin{array}{c}\text { Persentase } \\
(\mathbf{\%})\end{array}$ \\
\hline 1. & Sangat Setuju (SS) & & 16 & $40.00 \%$ \\
\hline 2. & Setuju (S) & & 22 & $60.00 \%$ \\
\hline 3. & Ragu-Ragu (RR) & \multirow{2}{*}{20} & 0 & $00.00 \%$ \\
\cline { 1 - 1 } & & & 0 & $00.00 \%$ \\
\hline 5. & Tidak Setuju (TS) & & 0 & $00.00 \%$ \\
\hline & Sangat Tidak Setuju (STS) & & $\mathbf{3 8}$ & $\mathbf{1 0 0 . 0 0 \%}$ \\
\hline
\end{tabular}

Sumber Data : Hasil Penelitian 2019

Berdasarkan hasil penyebaran angket yang disebarkan sebanyak 20 angket yang masing-masing indikator terdiri dari 2 pertanyaan sebagaimana terlihat pada tabel 3.8 di atas, mayoritas responden menjawab setuju sebanyak 60,00\%, hal ini berarti bahwa hubungan pendidikan kejuruan di bidang Produktivitas telah sesuai dengan yang diharapkan.

\section{Kualitas}

Berdasarkan angket yang disebarkan, peneliti memberikan penilaian mengenai kualitas yang dapat dilihat pada tabel 4.6 di bawah ini :

Tabel 4.6

Jawaban Responden Mengenai

Kualitas

$\mathrm{N}=20$

\begin{tabular}{|c|c|c|c|c|}
\hline No & Alternatif Jawaban & Angket & Frekuensi & $\begin{array}{c}\text { Persentase } \\
(\%)\end{array}$ \\
\hline 1. & Sangat Setuju (SS) & \multirow{5}{*}{20} & 8 & $20.00 \%$ \\
\hline 2. & Setuju (S) & & 28 & $75.00 \%$ \\
\hline 3. & Ragu-Ragu (RR) & & 2 & $5.00 \%$ \\
\hline 4. & Tidak Setuju (TS) & & 0 & $00.00 \%$ \\
\hline 5. & Sangat Tidak Setuju (STS) & & 0 & $00.00 \%$ \\
\hline & Jumlah & 20 & 38 & $100.00 \%$ \\
\hline
\end{tabular}


Sumber Data : Hasil Penelitian 2019

Berdasarkan hasil penyebaran angket yang disebarkan sebanyak 20 angket yang masing-masing indikator terdiri dari 2 pertanyaan sebagaimana terlihat pada tabel 4.6 di atas, mayoritas responden menjawab setuju sebanyak $75,00 \%$, hal ini berarti bahwa hubungan pendidikan kejuruan dengan produktivitas kerja di bidang kualitas telah sesuai dengan yang diharapkan.

\section{Kuantitas}

Berdasarkan angket yang disebarkan, peneliti memberikan penilaian mengenai kuantitas yang dapat dilihat pada tabel 4.7 di bawah ini :

Tabel 4.7

Jawaban Responden Mengenai

Kuantitas

$\mathrm{N}=20$

\begin{tabular}{|c|c|c|c|c|}
\hline No & Alternatif Jawaban & Angket & Frekuensi & $\begin{array}{c}\text { Persentase } \\
(\%)\end{array}$ \\
\hline 1. & Sangat Setuju (SS) & \multirow{5}{*}{20} & 3 & $7.50 \%$ \\
\hline 2. & Setuju (S) & & 24 & $65.00 \%$ \\
\hline 3. & Ragu-Ragu (RR) & & 11 & $27.50 \%$ \\
\hline 4. & Tidak Setuju (TS) & & 0 & $00.00 \%$ \\
\hline 5. & Sangat Tidak Setuju (STS) & & 0 & $00.00 \%$ \\
\hline & Jumlah & 20 & 38 & $100.00 \%$ \\
\hline
\end{tabular}

Sumber Data : Hasil Penelitian 2019

Berdasarkan hasil penyebaran angket yang disebarkan sebanyak 20 angket yang masing-masing indikator terdiri dari 2 pertanyaan sebagaimana terlihat pada tabel 4.7 di atas, mayoritas responden menjawab setuju sebanyak $65,00 \%$, hal ini berarti bahwa hubungan pendidikan kejuruan dengan produktivitas kerja di bidang kuantitas telah sesuai dengan yang diharapkan.

\section{Ketetapan waktu}

Berdasarkan angket yang disebarkan, peneliti memberikan penilaian mengenai ketetapan waktu yang dapat dilihat pada tabel 4.8 di bawah ini :

Tabel 4.8

Jawaban Responden Mengenai

Ketetapan waktu

$\mathrm{N}=20$

\begin{tabular}{|c|l|c|c|c|}
\hline No & \multicolumn{1}{|c|}{ Alternatif Jawaban } & Angket & Frekuensi & $\begin{array}{c}\text { Persentase } \\
(\boldsymbol{\%})\end{array}$ \\
\hline 1. & Sangat Setuju (SS) & 20 & 8 & $20.00 \%$ \\
\hline
\end{tabular}




\begin{tabular}{|c|c|c|c|c|}
\hline 2. & Setuju (S) & & 17 & $47.50 \%$ \\
\hline 3. & Ragu-Ragu (RR) & & 13 & $32.50 \%$ \\
\hline 4. & Tidak Setuju (TS) & & 0 & $00.00 \%$ \\
\hline 5 . & Sangat Tidak Setuju (STS) & & 0 & $00.00 \%$ \\
\hline & Jumlah & 20 & 38 & $100.00 \%$ \\
\hline
\end{tabular}

Sumber Data : Hasil Penelitian 2019

Berdasarkan hasil penyebaran angket yang disebarkan sebanyak 20 angket yang masing-masing indikator terdiri dari 2 pertanyaan sebagaimana terlihat pada tabel 4.8 di atas, mayoritas responden menjawab setuju sebanyak 47,50\%, hal ini berarti bahwa hubungan pendidikan kejuruan dengan produktivitas kerja di bidang ketetapan waktu telah sesuai dengan yang diharapkan.

\section{Inisiatif}

Berdasarkan angket yang disebarkan, peneliti memberikan penilaian mengenai Inisiatif yang dapat dilihat pada tabel 4.9 di bawah ini :

Tabel 4.9

Jawaban Responden Mengenai

Inisiatif

$\mathrm{N}=20$

\begin{tabular}{|c|c|c|c|c|}
\hline No & Alternatif Jawaban & Angket & Frekuensi & $\begin{array}{c}\text { Persentase } \\
(\%)\end{array}$ \\
\hline 1. & Sangat Setuju (SS) & \multirow{5}{*}{20} & 7 & $17.00 \%$ \\
\hline 2. & Setuju (S) & & 31 & $82.50 \%$ \\
\hline 3. & Ragu-Ragu (RR) & & 0 & $00.00 \%$ \\
\hline 4. & Tidak Setuju (TS) & & 0 & $00.00 \%$ \\
\hline 5. & Sangat Tidak Setuju (STS) & & 0 & $00.00 \%$ \\
\hline & Jumlah & 20 & 38 & $100.00 \%$ \\
\hline
\end{tabular}

Sumber Data : Hasil Penelitian 2019

Berdasarkan hasil penyebaran angket yang disebarkan sebanyak 20 angket yang masing-masing indikator terdiri dari 2 pertanyaan sebagaimana terlihat pada tabel 4.9 di atas, mayoritas responden menjawab setuju sebanyak $82,50 \%$, hal ini berarti bahwa hubungan pendidikan kejuruan dengan produktivitas kerja di bidang inisiatif telah sesuai dengan yang diharapkan

\section{Kerja Sama}

Berdasarkan angket yang disebarkan, peneliti memberikan penilaian mengenai Kerja Sama yang dapat dilihat pada tabel 4.10 di bawah ini : 
Tabel 4.10

Jawaban Responden Mengenai

Kerja Sama

$\mathrm{N}=20$

\begin{tabular}{|c|c|c|c|c|}
\hline No & Alternatif Jawaban & Angket & Frekuensi & $\begin{array}{c}\text { Persentase } \\
(\%)\end{array}$ \\
\hline 1. & Sangat Setuju (SS) & \multirow{5}{*}{20} & 13 & $32.50 \%$ \\
\hline 2. & Setuju (S) & & 18 & $50.00 \%$ \\
\hline 3. & Ragu-Ragu (RR) & & 7 & $17.50 \%$ \\
\hline 4. & Tidak Setuju (TS) & & 0 & $00.00 \%$ \\
\hline 5 . & Sangat Tidak Setuju (STS) & & 0 & $00.00 \%$ \\
\hline & Jumlah & 20 & 38 & $100.00 \%$ \\
\hline
\end{tabular}

Sumber Data : Hasil Penelitian 2019

Berdasarkan hasil penyebaran angket yang disebarkan sebanyak 20 angket yang masing-masing indikator terdiri dari 2 pertanyaan sebagaimana terlihat pada tabel 4.10 di atas, mayoritas responden menjawab setuju sebanyak $50,00 \%$, hal ini berarti bahwa hubungan pendidikan kejuruan dengan produktivitas kerja di bidang Kerja sama telah sesuai dengan yang diharapkan.

\section{Pengujian dengan Koefisien Korelasi Rank Spearman}

Menurut Sugiono (2008 : 356) Kolerasi Rank Spearman digunakan untuk mencari hubungan atau untuk menguji signifikasi masing-masing variable yang dihubungkan berbentuk ordinal, dan sumber data antar variable tidak harus sama.

Tabel 4.11

Tabel Pertolongan untuk menghitung rangking 


\begin{tabular}{|c|c|c|c|c|c|c|c|}
\hline NO & Responden & $\begin{array}{c}\text { Peranan Pendidikan } \\
\text { Kejuruan }(\mathrm{X})\end{array}$ & $\begin{array}{c}\text { Rank } \\
(\mathrm{X})\end{array}$ & $\begin{array}{c}\text { Produktivitas } \\
\text { Kerja (Y) }\end{array}$ & Rank (Y) & $X-Y(d)$ & (d.2) \\
\hline 1 & Responden 1 & 36 & 1 & 43 & 1 & 0 & 0 \\
\hline 2 & Responden 2 & 35 & 2,5 & 42 & 2,5 & 0 & 0 \\
\hline 3 & Responden 3 & 35 & 2,5 & 42 & 2,5 & 0 & 0 \\
\hline 4 & Responden 4 & 34 & 5,5 & 41 & 6,5 & -1 & 1 \\
\hline 5 & Responden 5 & 34 & 5,5 & 41 & 6,5 & -1 & 1 \\
\hline 6 & Responden 6 & 34 & 5,5 & 41 & 6,5 & -1 & 1 \\
\hline 7 & Responden 7 & 34 & 5,5 & 41 & 6,5 & -1 & 1 \\
\hline 8 & Responden 8 & 33 & 12,5 & 41 & 6,5 & 3 & 9 \\
\hline 9 & Responden 9 & 33 & 12,5 & 41 & 6,5 & 3 & 9 \\
\hline 10 & Responden 10 & 33 & 12,5 & 40 & 11,5 & 1 & 1 \\
\hline 11 & Responden 11 & 33 & 12,5 & 40 & 11,5 & 1 & 1 \\
\hline 12 & Responden 12 & 33 & 12,5 & 40 & 11,5 & 1 & 1 \\
\hline 13 & Responden 13 & 33 & 12,5 & 40 & 11,5 & 1 & 1 \\
\hline 14 & Responden 14 & 33 & 12,5 & 39 & 15 & -2.5 & 6.25 \\
\hline 15 & Responden 15 & 33 & 12,5 & 39 & 15 & -2.5 & 6.25 \\
\hline 16 & Responden 16 & 33 & 12,5 & 39 & 15 & -2.5 & 6.25 \\
\hline 17 & Responden 17 & 33 & 12,5 & 39 & 15 & -2.5 & 6.25 \\
\hline 18 & Responden 18 & 32 & 18,5 & 39 & 15 & 3.5 & 12.25 \\
\hline 19 & Responden 19 & 32 & 18,5 & 39 & 15 & 3.5 & 12.25 \\
\hline 20 & Responden 20 & 31 & 20 & 39 & 15 & 2 & 4 \\
\hline & & & & & & \multicolumn{2}{|c|}{$\sum d^{2}=81$} \\
\hline
\end{tabular}

Berdasarkan data hasil penelitian yang digambarkan pada tabel lampiran dengan menggunakan rumus korelasi rank spearman maka hasil dari variable (X) dengan Variable Y adalah sebagai berikut :

$$
\begin{aligned}
& r_{s}=1-\frac{6 \sum d_{i}^{2}}{n\left(n^{2}-1\right)} \\
& \mathrm{Rs}=1-\frac{(6) .81}{10\left(10^{2}-1\right)} \\
& \mathrm{Rs}=\frac{486}{990}=0,490
\end{aligned}
$$


Berdasarkan hasil perhitungan diatas diketahui bahwa nilai Rs adalah 0,490 berarti terdapat hubungan yang signifikan antara pendidikan kejuruan dengan produktifitas kerja personil Polres Kerinci.

\subsection{Koefisien Determinan}

Untuk Menentukan besarnya koefisien determinan variable $\mathrm{X}$ terhadap Variable Y adalah :

$\mathrm{Kd}=\mathrm{r}^{2} \times 100 \%$

Diketahui rxy 0,490

$\mathrm{Kd}=\mathrm{r}^{2} \times 100 \%$

$\mathrm{Kd} \quad=0,490^{2} \times 100 \%$

$=0,2401 \times 100 \%$

$\mathbf{2} \mathbf{2 4 , 0 1 \%}$

Dari hasil perhitungan diatas dapat diketahui besarnya hubungan pendidikan kejuruan terhadap produktivitas kerja personil Polres Kerinci sebesar 24,01\% berarti 24,01\% produktivitas kerja personil Polres Kerinci dipengaruhi oleh pendidikan kejuruan sedangkan 75, 99\% dipengaruhi oleh factor-faktor lain yang tidak penulis bahas dalam penelitian ini.

thitung $\quad \frac{=r \sqrt{n-2}}{\sqrt{1-r^{2}}}$

thitung $\quad \frac{=0,490 \sqrt{20-2}}{\sqrt{1-(0.490)^{2}}}$

thitung $\quad \frac{=0,490 \sqrt{ } 18}{\sqrt{ } 1-0,2401}$

thitung $\quad \frac{=0.490 .(4,2426)}{\sqrt{ } 0,7599}$

thitung $\quad \frac{=2,078874}{0,8717}$

t hitung $\quad=\mathbf{2 , 3 8 4}$

Kaidah pengujian :

Jika $t$ hitung $\geq \mathrm{t}$ tabel, maka signifikan

Jika t hitung $\leq \mathrm{t}$ tabel, maka tidak signifikan

Dari perhitungan diatas diperoleh nilai t hitung sebesar 2,384 sedangkan $\mathrm{t}$ tabel dengan tingkat kesalahn $\alpha=0,05 \mathrm{df}=\mathrm{n}-2=20-2=18$ adalah 2.101 sehingga t hitung $>\mathrm{t}$ tabel yaitu 2,384 > 2,101 dengan demikian maka berdasarkan kriteria 
uji signifikan, Ha diterima dan Ho ditolak artinya terdapat hubungan antara pendidikan kejuruan dengan produktivitas kerja personil Polres Kerinci.

\section{PENUTUP}

\subsection{Kesimpulan}

Berdasarkan dari uraian dan analisis bab-bab terdahulu maka dapat ditarik kesimpulan bahwa hubungan pendidikan dengan produktivitas kerja personil Polres Kerinci sebagai berikut :

1. Korelasi Rank Spearman dari perhitungan diketahui nilai RS adalah 0,490 berarti terdapat hubungan yang signifikan antara pendidikan kejuruan terhadap produktivitas kerja personil polres kerinci.

2. Koefisien Determinan dari hasil perhitungan dapat diketahui besarnya hubungan pendidikan kejuruan terhadap produktivitas kerja personil polres kerinci sebesar $24,01 \%$ berarti $24.01 \%$ produktivitas kerja personil polres kerinci dipengaruhi oleh hubungan pendidikan kejuruan sedangkan $75,99 \%$ dipegaruhi oleh factor-faktor lain yang tidak penulis bahas dalam penulisan ini.

Uji Signifikan hubungan pendidikan kejuruan dengan produktivitas Personil Polres Kerinci di peroleh hasil t hitung sebesar 2,384 sedangkan t tabel dengan tingkat kesalahn $\alpha=0,05 \mathrm{db}=\mathrm{n}-2=20-2=18$ adalah 2.101 sehingga $t$ hitung $>\mathrm{t}$ tabel yaitu 2,384 > 2,101 dengan demikian maka berdasarkan kriteria uji signifikan, Ha diterima dan Ho ditolak artinya bahwa hubungan pendidikan kejuruan mempunyai hubungan yang signifikan terhadap produktivitas kerja personil Polres Kerinci.

\subsection{Saran}

Berdasarkan hasil penelitian dilapangan mengenai hubungan pendidikan kejuruan dalam produktivitas kerja personil polres kerinci, berikut beberapa saran yang diharapkan dapat menjadi alternative dalam membantu memecahkan masalah antara lain :

1. Mengingat bahwa pendidikan kejuruan berhubungan signifikan terhadap produktivitas kerja personil polres kerinci , maka perlu mendapat perhatian penuh dari atasan maupun antar sesama personil sehingga akan memeberikan dampak positif terhadap produktifitas personil. 


\section{DAFTAR PUSTAKA}

Anonim, Peraturan kepala kepolisia Negara republic Indonesia nomor 14 tahun 2015. Tentang : system pendidikan kepolisian Negara republic indonesia

Beniss dan Michael, 1996.manajemen sumber daya manusia. Bumi aksara Jakarta Bachtiar, 2004. Manajemen pelatihan ketenaga kerjaan, Jakarta : bumi aksara

Dharma, 200. Kreatifitas sebagai esensi dan orientasi pengembanagn sumber daya manusia. Jurnal usahawan (online), (06) : 29-36

Fatoni, 2006. Tujuan pendidikan kejuruan, malang: bayu media

Gomes, 2005. Manajemen personalia dan sumber daya manusia, Yogyakarta : BPFE

Hasinuan, 2010. Pengertian pendidika kejuruan , : Jakarta selemba empat

Hadiyanto 1992. Peranan pendidikan kejuruan. Surabaya.

Luthans, 2000. Organization behavion, edisi ketujuh, McGraw Hill Inc. Singapura. Methew S O'Connel, Dennis.

Muliati, 2007, Sistem perencanaan dan pengendalian manajemen, edisi 1, penerbit Aditya media, Yogyakarta.

Muliati, 2007, peranan pendidikan kejuruan, Palembang.

Notoatmodjho 2003, Metode dalam pendidikan kejuruan. Surabaya.

Sondang 2003. Tahap-Tahap pendidikan kejuruan, Yogyakarta, Jakarta : BPFE

Soeharto 1998. Vocational education. Jakarta.

Sugiono 2006. Metode penelitian kualitatif, kualitatif dan R \& D.Bandung.Alfabeta Wursanto 1989. Manfaat Pendidikan kejuruan untuk peningkatan mutu SDM. 